\title{
A longitudinal study of amoebic gill disease on a marine Atlantic salmon farm utilising a real-time PCR assay for the detection of Neoparamoeba perurans
}

\author{
J. K. Downes ${ }^{1,2, *}$, K. Henshilwood ${ }^{1}$, E. M. Collins ${ }^{1}$, A. Ryan ${ }^{3}$, I. O'Connor ${ }^{2}$, \\ H. D. Rodger ${ }^{4}$, E. MacCarthy ${ }^{2}$, N. M. Ruane ${ }^{1}$ \\ ${ }^{1}$ Fish Health Unit, Marine Institute, Rinville, Oranmore, Co. Galway, Ireland \\ ${ }^{2}$ Marine \& Freshwater Research Centre, Galway Mayo Institute of Technology, Dublin Road, Galway, Ireland \\ ${ }^{3}$ Marine Harvest Ireland, Castletownbere, Co. Cork, Ireland \\ ${ }^{4}$ Vet Aqua International, Unit 7b, Oranmore Business Park, Oranmore, Co. Galway, Ireland
}

\begin{abstract}
Amoebic gill disease (AGD) is a proliferative gill disease of marine cultured Atlantic salmon Salmo salar, with the free-living protozoan Neoparamoeba perurans being the primary aetiological agent. The increased incidence of AGD in recent years presents a significant challenge to the Atlantic salmon farming industry in Europe. In this study, a real-time TaqMan ${ }^{\circledR}$ PCR assay was developed and validated to detect Neoparamoeba perurans on Atlantic salmon gills and further used to monitor disease progression on a marine Atlantic salmon farm in Ireland in conjunction with gross gill pathology and histopathology. The assay proved specific for $N$. perurans, with no cross-reactivity with the related species $N$. pemaquidensis, $N$. branchiphila or $N$. aestuarina, and was capable of detecting 2.68 copies of $N$. perurans DNA $\mathrm{\mu l}^{-1}$. Although the parasite was detected throughout the 18 mo period of this study, mortality peaks associated with clinical AGD were only recorded during the first 12 mo of the marine phase of the production cycle. The initial AGD outbreak resulted in peak mortality in Week 17, which was preceded by PCR detections from Week 13 onwards. Freshwater treatments were an effective method for controlling the disease, resulting in a reduction in the weekly mortality levels and also a reduction in the number of PCR-positive fish. In comparison to traditional diagnostic methods, our PCR assay proved to be highly sensitive and a valuable tool to monitor disease progression and, therefore, has the potential to provide information on the timing and effectiveness of treatments.
\end{abstract}

KEY WORDS: Amoebic gill disease $\cdot$ Neoparamoeba perurans $\cdot$ Diagnostics $\cdot$ Atlantic salmon

\section{INTRODUCTION}

Amoebic gill disease (AGD), caused by the parasitic amoeba Neoparamoeba perurans, is considered to constitute one of the major health challenges in marine cultured Atlantic salmon Salmo salar (Young et al. 2007, Adams et al. 2012) and was first described affecting farmed salmonids in Tasmania, Australia, and Washington state, USA, in the mid-1980s (Kent

*Corresponding author: jamie.downes@marine.ie et al. 1988). Over the last decade, the disease has become more widespread and has now been reported in the majority of Atlantic salmon-producing countries, including Norway (Steinum et al. 2008), Chile (Bustos et al. 2011) and Scotland (Rodger 2014). In addition to salmonids, AGD has been reported in other fish species, such as turbot Scophthalmus maximus (Dyková et al. 1998, Mouton et al. 2014), sea bass Dicentrarchus labrax, sharp-snout sea bream 
Diplodus puntazzo, ayu Plecoglossus altivelis (Nowak et al. 2014), and ballan wrasse Labrus bergylta (Karlsbakk et al. 2013).

In Ireland, AGD was first recorded in 1995 in a number of marine Atlantic salmon sites (Rodger \& McArdle 1996, Palmer et al. 1997) and continued to occur sporadically in a small number of sites since the first outbreaks (Bermingham \& Mulcahy 2007). Initial outbreaks of the disease in Ireland were confined to warm dry summers, although in recent years more widespread and sustained infections have become more common (Rodger \& McArdle 1996, Rodger 2014). If left untreated, AGD can cause significant mortality of up to $10 \%$ per week; however, freshwater baths of 2 to $4 \mathrm{~h}$ have proven to be an effective treatment strategy (Munday et al. 2001, Parsons et al. 2001). An $86 \%$ reduction in the number of amoeba remaining in the gills has been observed following freshwater baths (Clark et al. 2003). However, this method of treatment can add extra costs and is labourintensive, and several treatments may be required over the course of a production cycle (Nowak 2012).

Currently, the most financially viable and nondestructive means for the assessment of AGD on a commercial scale is through the gross pathological assessment of the gill arches to identify multifocal lesions characterised by white mucoid patches (Clark \& Nowak 1999, Adams et al. 2004) for which a gill scoring method has been developed (Taylor et al. 2009). However, this approach is a presumptive means by which to confirm the presence of AGD and is open to misinterpretation because the reactions of gills are limited and AGD lesions are difficult to distinguish from lesions caused by other pathogens or irritants. The technique and experience of the observer can also influence the outcome of the assessment (Adams et al. 2004). Therefore, the use of gill scores in the detection of lesions and patches only indicates an altered gill condition and does not specifically identify the aetiology (Adams et al. 2004). Lesions and patches do not always coincide with AGD in salmon and are less reliable in the early stages of an infection or less severe cases (Clark \& Nowak 1999). While clinical screening is accepted at the farm level as a monitoring tool, further investigation through histological and molecular means is required for accurate identification of the causal agent, particularly in new locations or to identify different species of the genus Neoparamoeba (Nowak et al. 2002). Histological diagnosis of AGD is confirmed through observation of gill hyperplasia, lamellar fusion, vesicle formation and the presence of amoebae with an associated parasome (Clark \&
Nowak 1999, Rodger 2014). Histology is limited in its ability to specifically identify Neoparamoeba spp. as they are morphologically indistinguishable (Dyková et al. 2000). Both gross and histological examinations have been reported to underestimate the prevalence of AGD, particularly in the lower prevalence range (Clark \& Nowak 1999).

In recent years, real-time PCR assays have become a more widely used diagnostic tool for the detection and identification of aquatic pathogens due to their robustness, sensitivity, high throughput and quick turnaround (Monis \& Giglio 2006, Purcell et al. 2011). Since $N$. perurans was first described as the causative agent of AGD (Young et al. 2007) in marinefarmed Atlantic salmon, there have been 2 real-time PCR methods published, based on both SYBR Green (Bridle et al. 2010) and TaqMan chemistries (Fringuelli et al. 2012). TaqMan ${ }^{\circledR}$ chemistry is generally thought to offer several advantages over SYBR ${ }^{\circledR}$ Green (Martenot et al. 2010, Fringuelli et al. 2012). In particular, the incorporation of minor-groove-binders (MGB) allows for the raising of melting temperatures of the probes (enabling the use of shorter probes) and the integration of the internal hydrolysis probe provides greater specificity in comparison to the intercalating dye assays due to the incorporation of any amplification products in the dye (Gunson et al. 2006, Purcell et al. 2011). The ability of the assay developed by Fringuelli et al. (2012) to detect $N$. perurans in field samples was not established, and although the assay performed well, issues occurred with false negative results (defined as a negative PCR result from a fish sample with clinical AGD) in a number of field samples tested by our laboratory (authors' unpubl. data). It was therefore decided to develop an alternative assay based on TaqMan chemistry.

Molecular diagnostics have the potential to fulfil a role as an early warning and monitoring tool that would greatly compliment traditional diagnostic methods, particularly in the early stages of infection when clinical signs may be absent. The aim of this study was to develop an alternative TaqMan® assay for the detection of $N$. perurans according to MIQE guidelines (Bustin et al. 2009) and investigate its application in monitoring the disease through a longitudinal study on a marine Atlantic salmon site during a single production cycle. Results obtained from the molecular assay were also compared to gill scores and histopathology results, to determine if the assay could potentially provide a more rapid, sensitive and highly specific diagnostic tool in order to provide timely information on the initial infection and the potential timing of treatments. 


\section{MATERIALS AND METHODS}

\section{Amoeba isolates and culture}

Neoparamoeba perurans was isolated from AGDaffected farmed Atlantic salmon in the west of Ireland using a method adapted from Morrison et al. (2004). Gill samples from infected salmon were excised and placed into $25 \mathrm{~cm}^{2}$ tissue culture flasks (Costar) filled with sterile seawater and transported, at ambient temperature, overnight to the laboratory. On arrival, the culture flasks were screened for the presence of amoeba adhered to the flask surface. Once observed, the seawater was removed, and the flask was rinsed 3 times with sterile seawater. Then, $0.5 \mathrm{ml}$ trypsinEDTA $0.05 \%\left(\right.$ Gibco $\left.^{\circledR}\right)$ was added to the flask and monitored for 3 to 5 min until the majority of amoebae were free-floating. A further 3 seawater washes were completed, and the seawater was transferred to a $50 \mathrm{ml}$ falcon tube which was then centrifuged at $800 \times g$ for $10 \mathrm{~min}$. The supernatant was discarded, and the pellet was re-suspended in $10 \mathrm{ml}$ sterile seawater (salinity 35) and poured onto a $0.1 \%$ malt yeast agar (MYA) plate. Amoebae cultures were maintained as described by Crosbie et al. (2012). Neoparamoeba pemaquidensis (ATCC $\left(50172^{\mathrm{TM}}\right.$ ) was obtained from the American Type Culture Collection (ATCC) and cultured according to the protocol provided. Additional ethanol-fixed samples of $N$. pemaquidensis (strain GILLNOR1/I), N. branchiphila (strain RP) and $N$. aestuarina (strain SU03) were kindly provided by the Institute of Parasitology, Academy of Sciences, Czech Republic.

\section{DNA extraction and conventional PCR of cultured amoebae}

All DNA extractions (cultured amoebae, ethanolfixed amoebae and gill samples) were performed using a QIAamp DNA Mini kit (Qiagen) according to the manufacturer's instructions for animal tissue, and the eluted DNA was stored at $-20^{\circ} \mathrm{C}$. To confirm the presence of $N$. perurans in the culture, amoebae were physically detached from the agar using a spreading bar and $10 \mathrm{ml}$ of the amoeba-seawater solution overlay transferred to a $15 \mathrm{ml}$ universal tube, which was immediately centrifuged at $800 \mathrm{~g}$ for $10 \mathrm{~min}$. The supernatant was discarded, and the amoeba pellet was lysed in $180 \mu \mathrm{l}$ of ATL buffer and $20 \mu \mathrm{l}$ of proteinase K. Extracted DNA was tested by conventional PCR as described by Young et al. (2008). Additional DNA extractions were performed on $N$. pemaquidensis, $N$. branchiphila and N. aestuarina, and universal eukaryotic primers (ERIB1 and ERIB10) selected from Barta et al. (1997) targeting the 18S ribosomal DNA gene were used for PCR amplification. All PCR products were run on a $1.5 \%(\mathrm{w} / \mathrm{v})$ agarose gel in TAE buffer (40 mM Tris, $20 \mathrm{mM}$ acetic acid, $2 \mathrm{mM}$ EDTA), stained with ethidium bromide and visualized with the Quantity One, 1-D Analysis System software on a UV Transluminator (Bio-Rad). PCR products confirmed as $N$. perurans were subsequently purified and sequenced commercially (Sequiserve, Germany).

\section{Real-time primer and probe design}

The PCR primer pair and TaqMan MGB probe were selected from alignments of previously published sequence data of the 18S rRNA gene sequences of $N$. perurans (EF216903-EF216905). Based on this alignment, a forward primer 'NP1' (5'-AAAAGACCATGCGATTCGTAAAGT-3'), a reverse primer 'NP2' (5'-CATTCTTTTCGGAGAGTGGAAATT-3') and a probe 'NPP' (6-FAM- ATCATGATTCACCATATGTT-MGB) were designed using Primer Express (Life Technologies). The primers generated an amplicon of $70 \mathrm{bp}$ and were obtained from Sigma; the probe was from Life Technologies.

\section{TaqMan real-time PCR}

Following assay pre-optimisation experiments (data not shown) using the Applied Biosystems standard protocols (http://doc.appliedbiosystems.com), each real-time PCR reaction mixture contained $5 \mu \mathrm{l}$ template, $12.5 \mu \mathrm{l}$ TaqMan ${ }^{\circledR}$ Universal 2 Master Mix (Applied Biosystems), $300 \mathrm{nM} \mathrm{NP1,} 900 \mathrm{nM}$ NP2, $200 \mathrm{nM}$ NPP and made up to $25 \mu \mathrm{l}$ with $\mathrm{MBG} \mathrm{H}_{2} \mathrm{O}$. The thermal profile of the real-time PCR program consisted of $15 \mathrm{~min}$ at $95^{\circ} \mathrm{C}$, followed by 45 cycles of $15 \mathrm{~s}$ at $95^{\circ} \mathrm{C}$ and $30 \mathrm{~s}$ at $56^{\circ} \mathrm{C}$ in an Applied Biosystems AB7500 real-time instrument and associated software. Each run included a positive control, a negative control and a negative-process control (a blank sample extracted along with the gill samples). An internal process control (IPC; Life technologies) and external process control (salmonid elongation factor- $1 \alpha_{i}$ Bruno et al. 2007) were used for every 20 samples tested.

\section{Validation of reaction efficiency, sensitivity and specificity}

Once confirmed as $N$. perurans, the PCR product produced was then cloned into the pGEM $^{\circledR}$ Easy 
Vector systems (Promega) and purified using GenElute Plasmid Miniprep Kit (Sigma) according to the manufacturer's instructions. The plasmid concentration was measured spectrophotometrically at $260 \mathrm{~nm}$, and the value obtained was used to determine plasmid copy numbers, calculated using a DNA copy number calculator (http://cels.uri.edu/gsc/cndna.html). To determine the efficiency of the assay, Atlantic salmon gills from freshwater were spiked with $N$. perurans plasmid DNA and taken through the extraction process as described above. A 10-fold serial dilution was carried out in quadruplicate, and each of the log dilutions were subjected to real-time amplification as previously described. Only dilutions that provided $\mathrm{C}_{\mathrm{t}}$ values in all replicates were used to generate a standard curve, which was created by plotting the $\mathrm{C}_{\mathrm{t}}$ values against the 10 -fold dilutions of N. perurans. Amplification efficiency of the realtime PCR assay was established based on the $C_{t}$ slope method (Efficiency $\left.(\mathrm{Ex})=\left[10^{(-1 / \text { slope })}\right]-1\right)$, and the linearity was determined as the coefficient of correlation $\left(\mathrm{R}^{2}\right)$. The dilution series was also used to determine the sensitivity of the assay. The lowest dilution which provided $\mathrm{C}_{\mathrm{t}}$ readings in all replicates was investigated further via a 2 -fold dilution series tested in quadruplicate, in order to determine the limit of detection. This final dilution was then analysed a further 20 times to assess the precision of the assay at a $95 \%$ confidence level. The specificity of the assay primers and probe were initially determined theoretically using the Basic Local Alignment Search Tool (BLAST) (http://blast.ncbi.nlm.nih.gov/ Blast.cgi) to identify potential cross reactivity with other species including Atlantic salmon. In addition, DNA samples extracted from $N$. pemaquidensis, $N$. branchiphilia and $N$. aestuarina were also tested using the real-time PCR assay.

\section{Reproducibility}

The reproducibility of the assay was evaluated by investigating 7 different gill samples in triplicate. These samples had previously tested positive by both the Fringuelli et al. (2012) assay and the assay described in this manuscript. All samples were tested on 3 consecutive days, and results were analysed in order to determine the coefficient of variation for intra-assay variance and also inter-assay variance, i.e. the variance in each of the sample triplicates when compared between different PCR runs. The reproducibility was analysed by relative standard deviation.

\section{Longitudinal study site and sampling details}

The longitudinal study was carried out on a marine Atlantic salmon fish farm on the south west coast of Ireland. The site is fully oceanic with little or no variation in salinity levels throughout the year. It is situated in an area that receives relatively high exposure, experiencing a mean wave height of $1.97 \mathrm{~m}$ and a maximum wave height of $8.28 \mathrm{~m}$. The approximate depth of the bay where the site is situated is $23 \mathrm{~m}$. In total, 800000 salmon smolts with an average weight of $60 \mathrm{~g}$ were transferred to the sea site during late April and early May 2013. Sampling commenced 4 wk post transfer on 3 May 2013, when the average weight of the fish was $85 \mathrm{~g}$, and continued until 19 September 2014, when the average weight of the fish was $4.6 \mathrm{~kg}$.

At each sampling point, 5 feeding fish were selected from 2 fixed cages on site $(n=10)$ using a hand net. Moribund fish were avoided to ensure that fish sampled were representative of the population as a whole. At each sampling point, gill scoring (0 to 5) was conducted on site using the method adapted from Taylor et al. (2009) for AGD assessment. The second gill arch on the left-hand side was excised from each fish and immediately fixed in 10\% neutral buffered formalin for histological processing. Sections (5 $\mu \mathrm{m})$ from paraffin-embedded gill samples were stained with haematoxylin and eosin and examined on an Olympus BX51 microscope. Based on the typical histopathology associated with AGD (fusion of the lamellae, hyperplasia and vesicle formation) and the presence of amoebae (Adams \& Nowak 2001, Mitchell et al. 2012), a histopathology scoring scale was established for this study. The scoring system was based on Mitchell et al. (2012) and was applied to illustrate the progression and severity of the gill lesions in fish where AGD developed: a score of $0=$ normal gill, $1=$ low pathology ( $<10 \%$ of gill filament affected), $2=$ moderate patho$\operatorname{logy}(<50 \%$ of gill filament affected), and $3=$ severe pathology ( $>50 \%$ of gill filament affected).

The second gill arch on the right-hand side was excised from each fish and immediately placed in $1 \mathrm{ml}$ RNA Later (Sigma) for molecular analysis. Total DNA was extracted from 25 mg of gill filament using the DNA Mini kit (Qiagen) and screened for N. perurans by real-time PCR as described above.

\section{In situ hybridisation}

Sections were hybridised with a digoxigenin (DIG)labelled oligonucleotide probe specific to $N$. perurans as previously described (Young et al. 2008). Gill fila- 
ment sections $(7 \mu \mathrm{m})$ were placed on poly-L-lysine coated glass slides (Sigma), and each section was deparaffinised in a series of xyleen/ethanol washes. The proteinase K step was omitted. Sections were allowed to dry, and a frame-seal (Biozym) was placed on the slides to make a chamber before overlaying with a mixture of $1 \mu \mathrm{l}$ of PCR product (cultured amoebae DNA amplified using primers by Young et al. [2008]) in $99 \mu \mathrm{l}$ hybridisation buffer ( $5 \mathrm{ml}$ formamide [Sigma], $1 \mathrm{~g}$ dextran sulphate [Sigma], $2 \mathrm{ml}$ SSC buffer 20 [Roche], 2.5 mg tRNA [Roche], $200 \mu$ l Denhart's solution 50 [Sigma] and $2.8 \mathrm{ml} \mathrm{dH}_{2} \mathrm{O}$ to a total volume of $10 \mathrm{ml}$ ). A cover slip was added, and the DNA was denatured at $94^{\circ} \mathrm{C}$ for $5 \mathrm{~min}$ in a slide block (Bio-Rad Thermal cycler), then cooled directly on ice prior to overnight incubation at $42^{\circ} \mathrm{C}$. The coverslips were removed, and the slides were sequentially washed in $2 \mathrm{SSC}$ buffer for $10 \mathrm{~min}(2 \times), 0.4 \times \mathrm{SSC}$ buffer at $42^{\circ} \mathrm{C}$ for $10 \mathrm{~min}$ followed by $5 \mathrm{~min}$ in DIG1 buffer $(0.10 \mathrm{M}$ maleic acid, $0.15 \mathrm{M} \mathrm{NaCl}$ ). Each slide was then overlayed with $400 \mu$ l of DIG2 buffer (1\% blocking reagent [Roche] in DIG 1) and incubated in a humid box at room temperature for $30 \mathrm{~min}$. Each section was given a short wash in DIG1 buffer prior to an overlay of $400 \mu \mathrm{l}$ of DIG 2 buffer plus 1:500 anti-DIG-alkaline phosphate (Roche) and incubated for $1 \mathrm{~h}$ in a humid box at room temperature. Slides were washed for 10 min in DIG1 $(2 \times)$ and DIG3 (0.1 M Tris, $0.1 \mathrm{M} \mathrm{NaCl}$, and $0.05 \mathrm{M} \mathrm{MgCl}_{2} \mathrm{H}_{2} \mathrm{O}$ ) for $5 \mathrm{~min}$. Each section was overlayed with $200 \mu \mathrm{l}$ of NBT/BCIP (Roche) in DIG 3 and incubated for $25 \mathrm{~min}$. The colour reaction was stopped by 5 min incubation in DIG4 (10 mM Tris, $1 \mathrm{mM}$ EDTA) buffer followed by counter-staining for 1 min with 0.5\% Bismark Brown Y (Sigma) solution. Slides were then dehydrated in ethanol and xylene, before a coverslip was added.

\section{Temperature and farm data}

Temperature data were obtained using StowAway® ${ }^{\circledR i d b i t}{ }^{\mathrm{TM}}$ sensors which were attached to 1 cage pontoon at the site. Sensors were placed at depth of $10 \mathrm{~m}$ and logged temperature on an hourly basis as part of the Marine Institute Temperature Monitoring Programme (www.marine.ie/home/publicationsdata/data/IMOS/IMOSTidbit.htm). Gill scores, mortalities and the number of freshwater bath treatments administered for AGD were recorded by the site manager. Mortality data was docu- mented as the total weekly mortality per cage. Freshwater baths ( 2 to $3 \mathrm{~h}$ ) were carried out at a number of time points during this study. These treatments were triggered based on the results of weekly gill checks, when farms observed 30 to $40 \%$ of fish with a score of 2 or above (Rodger 2014).

\section{RESULTS}

\section{DNA extraction and conventional PCR of cultured amoebae}

Neoparamoeba perurans was successfully isolated and cultured at $18^{\circ} \mathrm{C}$ on MYA plates, with washing occurring every $3 \mathrm{~d}$ and amoebae seeded onto fresh plates every 2 wk. Cultured isolates (Fig. 1A) were tested via conventional PCR using $N$. perurans specific primers (Young et al. 2008) to confirm their identity. Amoebae were also observed in fresh gill mucus scrapes from infected fish (Fig. 1B). Sequenced PCR products were analysed via BLAST and showed 99\% similarity with sequences from Norway (KF146713), Australia (GU574794) and Chile (GQ407108). The $18 \mathrm{~S}$ rDNA sequences retrieved from the ethanol fixed samples confirmed the identity of each amoeba species, following BLAST analysis.

\section{Real time primer and probe design}

Following assay pre-optimisation experiments, primer/probe final concentrations of $300 \mathrm{nM}$ NP1, 900 nM NP2 primer and 200 nM NPP probe were used in all tests. 


\section{Validation of reaction efficiency, sensitivity and specificity}

The standard curve generated following testing of a 7-log dilution series of the amoeba plasmid spiked in Atlantic salmon gill had a slope of -3.363 and an amplification efficiency of $98.44 \%$ with a linear correlation coefficient of $\mathrm{R}^{2}=0.999$ (Fig. 2). The final dilution that produced a cycle threshold (Ct) value in all quadruplicates was $10^{-7}$ (Fig. 2). Analysis of serial dilutions $\left(1: 2,1: 3,1: 4,1: 5,1: 6\right.$, etc.) of the $10^{-7}$ dilution showed that consistent results were found in all replicates up to the 1:5 dilution, giving the assay a reproducible cut-off $\mathrm{Ct}$ value of 40.13 (Table 1) equivalent to 2.68 DNA copies per $\mathrm{\mu l}^{-1}$. This dilution was tested a further 20 times in duplicate to assure a $95 \%$ confidence (Table 2). Individual BLAST searches conducted on both the primers and probe sequences showed no similarity to any other amoeba species. When tested experimentally with DNA isolated from $N$. pemaquidensis, $N$. branchiphila and $N$. aestuarina, no amplification was observed.

\section{Reproducibility}

The mean intra-assay variances ranged from 0.05 to $0.62 \%$ in the triplicates of the 7 samples tested. Based on the 3 separate repeats of the PCR assay, the inter-assay variation ranged from 0.24 to $0.48 \%$ (Table 3).

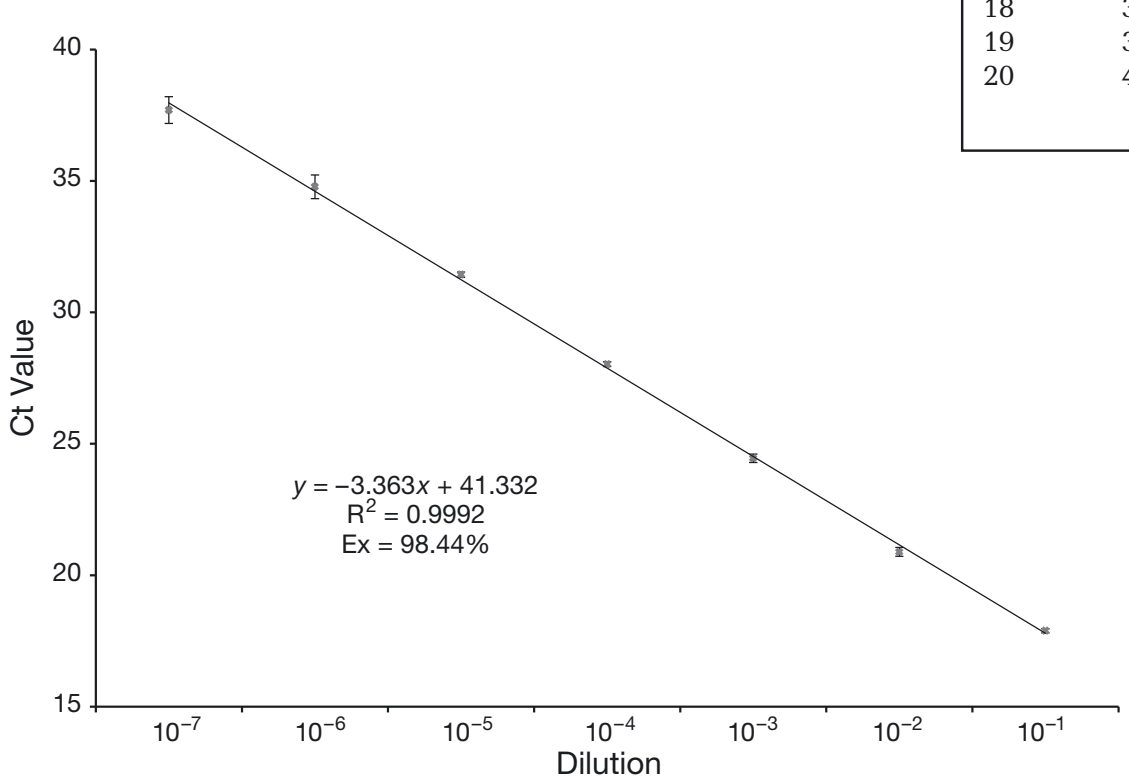

Fig. 2. Amplification of quadruplicate log dilutions of Neoparamoeba perurans plasmid DNA in Atlantic salmon gill samples. At each point, the $\mathrm{Ct}$ value was plotted against the dilution. Ex: amplification efficiency
Table 1. Determination of the working limit of detection for the TaqMan assay. The working limit of detection is in bold. nd: not determined

\begin{tabular}{|ccccccc|}
\hline & Ct1 & Ct2 & Ct3 & Ct4 & Mean & SD \\
\hline $1: 2$ & 37.71 & 37.43 & 36.64 & 36 & 36.95 & 0.78 \\
$1: 3$ & 38.03 & 39.72 & 38.9 & 37.42 & 38.52 & 1.01 \\
$1: 4$ & 40.12 & 38.66 & 38.96 & 39.24 & 39.25 & 0.63 \\
$1: 5$ & 40.31 & 40.02 & 40.36 & 39.81 & $\mathbf{4 0 . 1 3}$ & 0.26 \\
$1: 6$ & 42.83 & nd & 40.28 & 41.59 & 41.57 & 1.28 \\
\hline
\end{tabular}

Table 2. The final dilution of the standard curve (Fig. 1) which produced $\mathrm{Ct}$ values in all replicates was further analysed and tested 20 times (in duplicate) to determine the precision of the assay at a $95 \%$ confidence level

\begin{tabular}{|lcccc|}
\hline & Ct value 1 & Ct value 2 & Mean & SD \\
\hline 1 & 37.48 & 38.81 & 38.15 & 0.94 \\
2 & 38.96 & 38.07 & 38.52 & 0.63 \\
3 & 39.57 & 40.44 & 40.01 & 0.62 \\
4 & 39.54 & 39.24 & 39.39 & 0.21 \\
5 & 39.32 & 38.51 & 38.92 & 0.57 \\
6 & 38.67 & 39.44 & 39.06 & 0.54 \\
7 & 39.5 & 39.22 & 39.36 & 0.20 \\
8 & 38.75 & 39.33 & 39.04 & 0.41 \\
9 & 40.47 & 40.94 & 40.71 & 0.33 \\
10 & 39.53 & 38.47 & 39.00 & 0.75 \\
11 & 39.49 & 40.26 & 39.88 & 0.54 \\
12 & 39.25 & 39.21 & 39.23 & 0.03 \\
13 & 39.51 & 40.14 & 39.83 & 0.45 \\
14 & 39.57 & 39.7 & 39.64 & 0.09 \\
15 & 39.82 & 39.39 & 39.61 & 0.30 \\
16 & 40.39 & 39.45 & 39.92 & 0.66 \\
17 & 40.58 & 39.94 & 40.26 & 0.45 \\
18 & 39.85 & 39.01 & 39.43 & 0.59 \\
19 & 38.99 & 39.36 & 39.18 & 0.26 \\
20 & 40.15 & 39.55 & 39.85 & 0.42 \\
& & & 0.60 & 0.45 \\
\hline
\end{tabular}

\section{Longitudinal study: temperature, mortality and treatment dates}

Sea water temperatures, \% weekly mortality rates and treatment dates for the entire production cycle are shown in Fig. 3. Sea temperatures ranged from $7.8^{\circ} \mathrm{C}$ in April 2013 to $19.2^{\circ} \mathrm{C}$ in July 2013. Two freshwater bath treatments were carried out on all cages in August (Week 18) and September 2013 (Week 24), with a further 4 treatments occurring on a number of pens on site in December 2013 (twice, Weeks 34 and 37) and in January (Week 39) and June (Week 61) 2014. Three periods of 
Table 3. Real-time PCR Ct values from the reproducibility testing using 7 samples of cultured Neoparamoeba perurans tested in triplicate. The mean $( \pm \mathrm{SD})$ intra-assay variances ranged from 0.05 to $0.62 \%$, while the inter-assay variance ranged from 0.24 to $0.48 \%$

\begin{tabular}{|c|c|c|c|c|c|c|c|c|c|c|c|}
\hline \multirow[t]{2}{*}{ Sample } & \multicolumn{3}{|c|}{$\longrightarrow$ PCR assay $1-$} & \multicolumn{3}{|c|}{$\longrightarrow$ PCR assay $2-$} & \multirow{2}{*}{$\overline{\mathrm{Ct} \text { value }}$} & \multicolumn{2}{|c|}{ PCR assay $3-$} & \multicolumn{2}{|c|}{ Inter-assay variance } \\
\hline & Ct value & Mean & $\mathrm{RSD} \%$ & Ct value & Mean & $\mathrm{RSD} \%$ & & Mean & $\mathrm{RSD} \%$ & Mean & $\mathrm{RSD} \%$ \\
\hline 1 & $\begin{array}{c}33.5 \\
33.54 \\
33.45\end{array}$ & $33.50 \pm 0.05$ & 0.13 & $\begin{array}{l}33.43 \\
33.32 \\
33.44\end{array}$ & $33.40 \pm 0.07$ & 0.2 & $\begin{array}{l}33.49 \\
33.62 \\
33.55\end{array}$ & $33.55 \pm 0.07$ & 0.19 & $33.48 \pm 0.09$ & 0.26 \\
\hline 2 & $\begin{array}{l}32.55 \\
32.54 \\
32.72\end{array}$ & $32.60 \pm 0.1$ & 0.31 & $\begin{array}{l}32.42 \\
32.56 \\
32.54\end{array}$ & $32.51 \pm 0.08$ & 0.23 & $\begin{array}{l}32.45 \\
32.38 \\
32.48\end{array}$ & $32.44 \pm 0.05$ & 0.16 & $32.52 \pm 0.10$ & 0.31 \\
\hline 3 & $\begin{array}{c}32.57 \\
32.61 \\
32.7\end{array}$ & $32.63 \pm 0.07$ & 0.2 & $\begin{array}{l}32.42 \\
32.53 \\
32.61\end{array}$ & $32.52 \pm 0.10$ & 0.29 & $\begin{array}{l}32.63 \\
32.63 \\
32.59\end{array}$ & $32.62 \pm 0.02$ & 0.07 & $32.59 \pm 0.08$ & 0.24 \\
\hline 4 & $\begin{array}{l}31.91 \\
31.93 \\
31.94\end{array}$ & $31.93 \pm 0.02$ & 0.05 & $\begin{array}{c}31.55 \\
31.94 \\
31.8\end{array}$ & $31.76 \pm 0.20$ & 0.62 & $\begin{array}{l}31.68 \\
31.83 \\
31.78\end{array}$ & $31.76 \pm 0.08$ & 0.24 & $31.82 \pm 0.13$ & 0.42 \\
\hline 5 & $\begin{array}{l}37.25 \\
37.46 \\
37.08\end{array}$ & $37.26 \pm 0.19$ & 0.51 & $\begin{array}{l}36.95 \\
37.19 \\
37.28\end{array}$ & $37.14 \pm 0.17$ & 0.46 & $\begin{array}{c}37 \\
37 \\
36.95\end{array}$ & $36.98 \pm 0.03$ & 0.08 & $37.13 \pm 0.18$ & 0.48 \\
\hline 6 & $\begin{array}{c}34.32 \\
34.7 \\
34.37\end{array}$ & $34.46 \pm 0.21$ & 0.6 & $\begin{array}{c}34.36 \\
34.51 \\
34.5\end{array}$ & $34.46 \pm 0.08$ & 0.24 & $\begin{array}{c}34.43 \\
34.6 \\
34.64\end{array}$ & $34.56 \pm 0.11$ & 0.32 & $34.49 \pm 0.13$ & 0.39 \\
\hline 7 & $\begin{array}{l}33.41 \\
33.68 \\
33.69\end{array}$ & $33.59 \pm 0.16$ & 0.47 & $\begin{array}{c}33.5 \\
33.71 \\
33.63\end{array}$ & $33.61 \pm 0.11$ & 0.32 & $\begin{array}{l}33.39 \\
33.53 \\
33.37\end{array}$ & $33.43 \pm 0.09$ & 0.26 & $33.55 \pm 0.14$ & 0.41 \\
\hline
\end{tabular}

elevated mortality occurred during the production cycle, resulting in peak weekly mortality rates of 2,3 and $2.5 \%$ respectively. However, after Week 38 (January 2014), weekly mortality rates remained below $0.5 \%$. The first increase in mortality, which was due to AGD, occurred in Week 13, peaked at Week 17 and declined from Week 18 onwards following a freshwater treatment. Mortalities due to AGD gradually increased again from Week 22 but did not peak due to a treatment in Week 24. A sharp increase in mortality occurred in Week 26 due to a bloom of zooplankton, more specifically Pelagia noctiluca. The third period of high mortality, due to AGD, occurred between Weeks 32 and 37 and resulted in a number of freshwater treatments for specific pens on site only (Fig. 3).

\section{Longitudinal study: PCR results, gill scores, histological scores}

Sampling was initiated in Week 4 (3 May 2013) and completed in Week 76 (19 September 2014) before harvesting began. The average gill score, average histological score and \% PCR-positive results for the entire production cycle are shown in Table 4 . The first
PCR-positive samples were detected in Week 4 ; however, all fish sampled in Weeks 6, 8 and 9 were negative (Table 4, Fig. 4A). The numbers of PCR-positive fish started to increase from Week 12 until Week 16, when all fish were positive and coincided with the first peak of mortality. Following the freshwater treatment in Week 18, only $10 \%$ of fish were PCR-positive in Week 19, increasing to $80 \%$ by Week 24 due to the second AGD outbreak. Following the second full site treatment, $30 \%$ of fish were positive in Week 28 before increasing again to $100 \%$ by Week 32, prior to the third AGD outbreak on site. During the second half of the production cycle, PCR-positive fish were detected up to the pre-harvest period in Week 76. The first increase in mean gill score was observed in Week 16 (31 July 2013), coinciding with the first outbreak of AGD with average gill score of 2.5 (Fig. 4B). Following treatment, the mean gill score declined to $<0.5$ by Week 21 before increasing again (to 1.5) in Week 24 after the second AGD outbreak. During the third AGD outbreak and for the remainder of the production cycle, moderate mean gill scores were observed but were never greater than 2 . The average histological gill score first increased (to 2.5) in Week 16 (Fig. 4C) and gradually reduced following treatment showing a similar pattern to the mean gill 


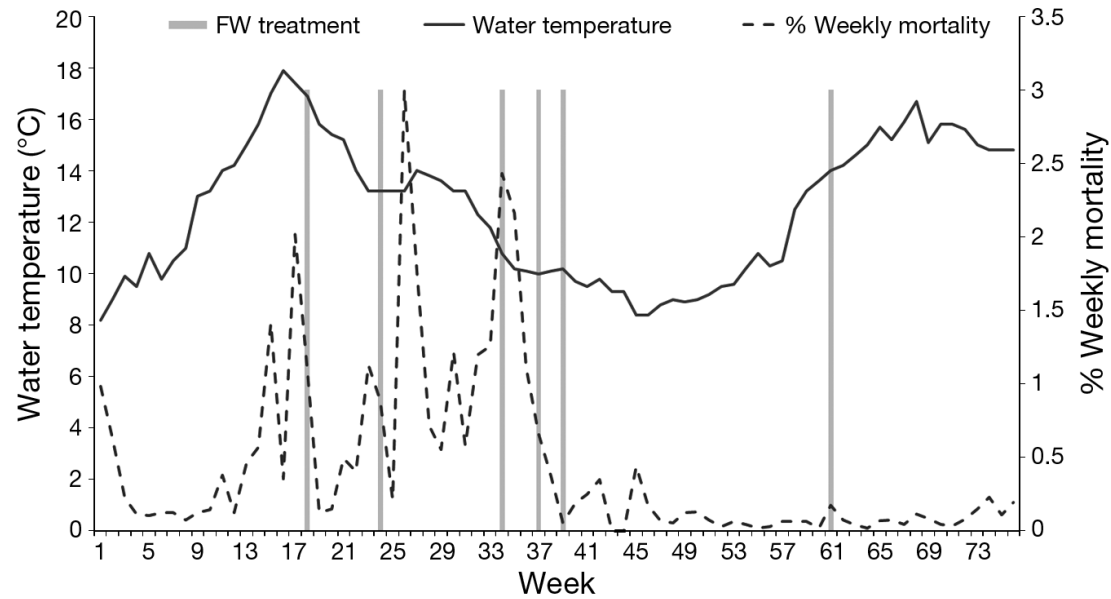

Fig. 3. Seawater temperatures, \% weekly mortality rates of Atlantic salmon and the dates of freshwater bath treatments throughout the marine production cycle during the longitudinal study scores. Amoebae were first observed histologically in Week 16 (Table 4). The presence of $N$. perurans was confirmed by in situ hybridisation (Fig. 5A). Two further increases in gross pathology were observed in 2013 before a decline to minimal levels in January and February (Weeks 36 to 44). Histopathology scores were recorded over the full range of the scoring method (Fig. 5B-D), and at each sampling point, some mild form of pathology was consistently observed. Amoebae were observed only on 3 occasions: in Weeks 16 and 32 during the first and third AGD outbreaks and again in Week 45 (Table 4 ).

Table 4. Average gill score, average histological score (with comments) and \% PCR-positive Atlantic salmon throughout the marine production cycle during the longitudinal study. Dates given as dd/mm/yyyy. N/A: not applicable





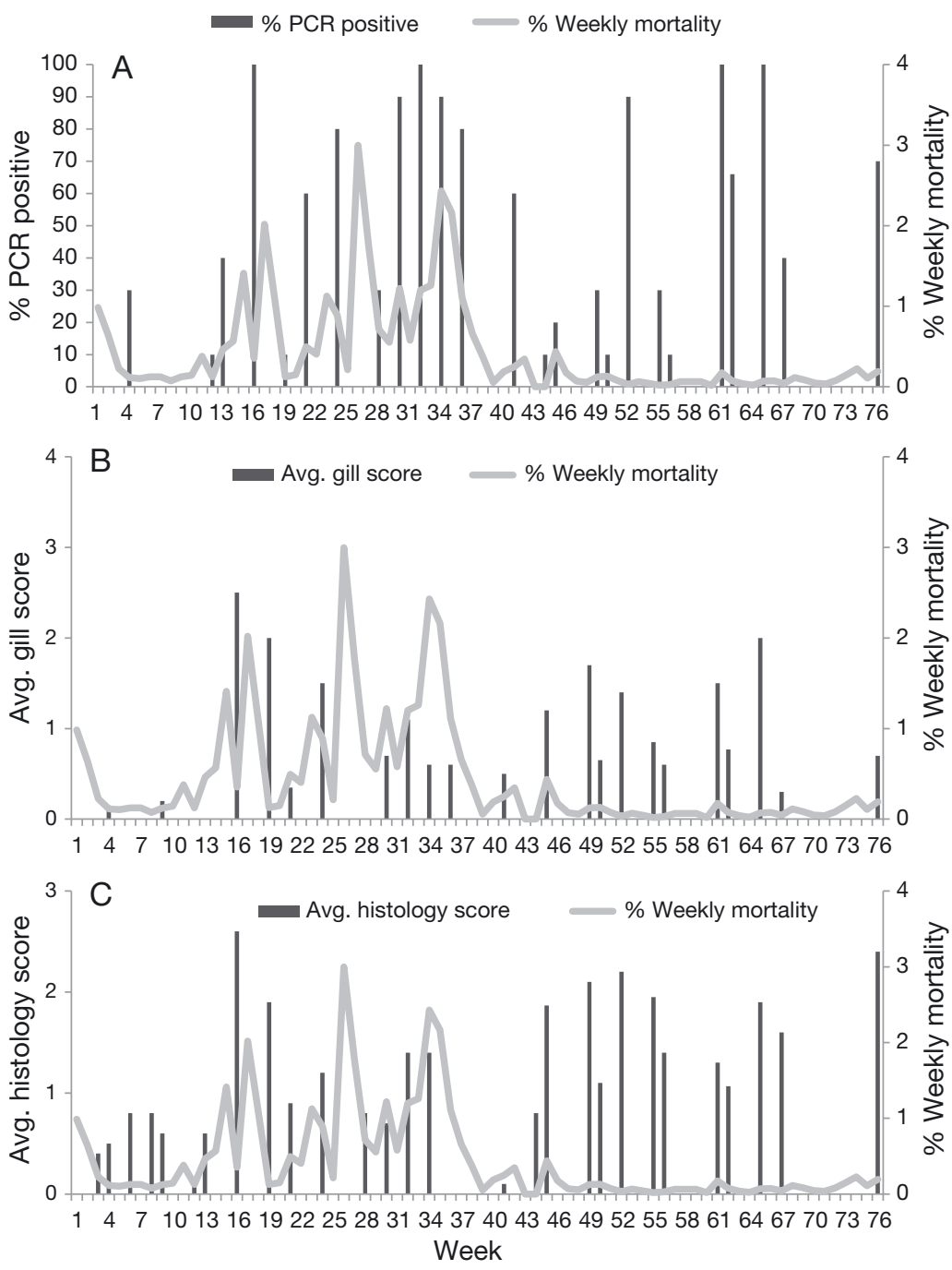

Fig. 4. Weekly mortality rates versus (A) \% PCR-positive fish, (B) average gill scores, and (C) average histology scores, throughout the marine production cycle of Atlantic salmon during the longitudinal study

remained a major issue since then (Rodger 2014). The rapid detection of pathogens is essential for the implementation of an effective health management plan in aquaculture. This study aimed to develop a realtime PCR assay for the detection of Neoparamoeba perurans in Atlantic salmon gill samples and to validate the assay as a surveillance tool for AGD through the marine grow-out phase of the production cycle. The assay reported in this study was designed to amplify a smaller (70 bp) segment of the $N$. perurans 18S rRNA gene than the one described by Fringuelli et al. (2012). The assay optimised for the detection of $N$. perurans had a high efficiency of $98.44 \%$ and an $\mathrm{R}^{2}$ value of 0.999 , within the accepted levels of $100 \pm 10 \%$ (Purcell et al. 2011), and was able to repeatedly detect as low as 2.68 copy numbers of $N$. perurans DNA $\mu l^{-1}$, which is at the theoretical limit of sensitivity for real-time PCR assays (Bustin et al. 2009).

Following optimisation, the assay was then utilised in a longitudinal study for the detection of $N$. perurans on a farm site in the south west of Ireland. Longitudinal studies have been used to investigate a range of diseases of importance in aquaculture, such as heart and skeletal muscle inflammation (Kongtorp et al. 2006), pancreas disease (Graham et al. 2010) and AGD (Clark \& Nowak 1999). These studies provide important information on potential risk factors, impact of the disease and on the performance of diagnostic methods. This study covered the full marine production cycle from Week 4 post-transfer (3 May

\section{DISCUSSION}

Over the last decade, gill pathologies have become an increasing problem for the Atlantic salmon aquaculture industry in Northern Europe (Rodger et al. 2011). In recent years, jellyfish, zooplankton, phytoplankton, bacteria, viruses and parasites have all been identified as causing fish kills and significant gill pathology in farmed salmonids (Mitchell \& Rodger 2007, Doyle et al. 2008, Baxter et al. 2011), although, in terms of economic impact, the most significant gill disease currently affecting the industry is AGD.

In 2011, AGD re-emerged as a significant disease of marine farmed Atlantic salmon in Ireland and has
2013) up until Week 76 (19 September 2014). During this period, 3 peaks in mortality were recorded on the site, each one due to an outbreak of AGD, although the second mortality peak was also due to a large bloom of Pelagia noctiluca, known to cause significant pathology and mortality in farmed Atlantic salmon (Marcos-López et al. 2014). Mortality started to increase during Week 13, at a time when the seawater temperature first rose above $15^{\circ} \mathrm{C}$. There was an increase in the mean gill score and histological score in Week 16, when pathology consistent with AGD as well as amoebae were observed on the gills. It is recognised that the histological gill score may have been influenced by the buffered formalin fixative used in this study. The use of an alternative fixa- 

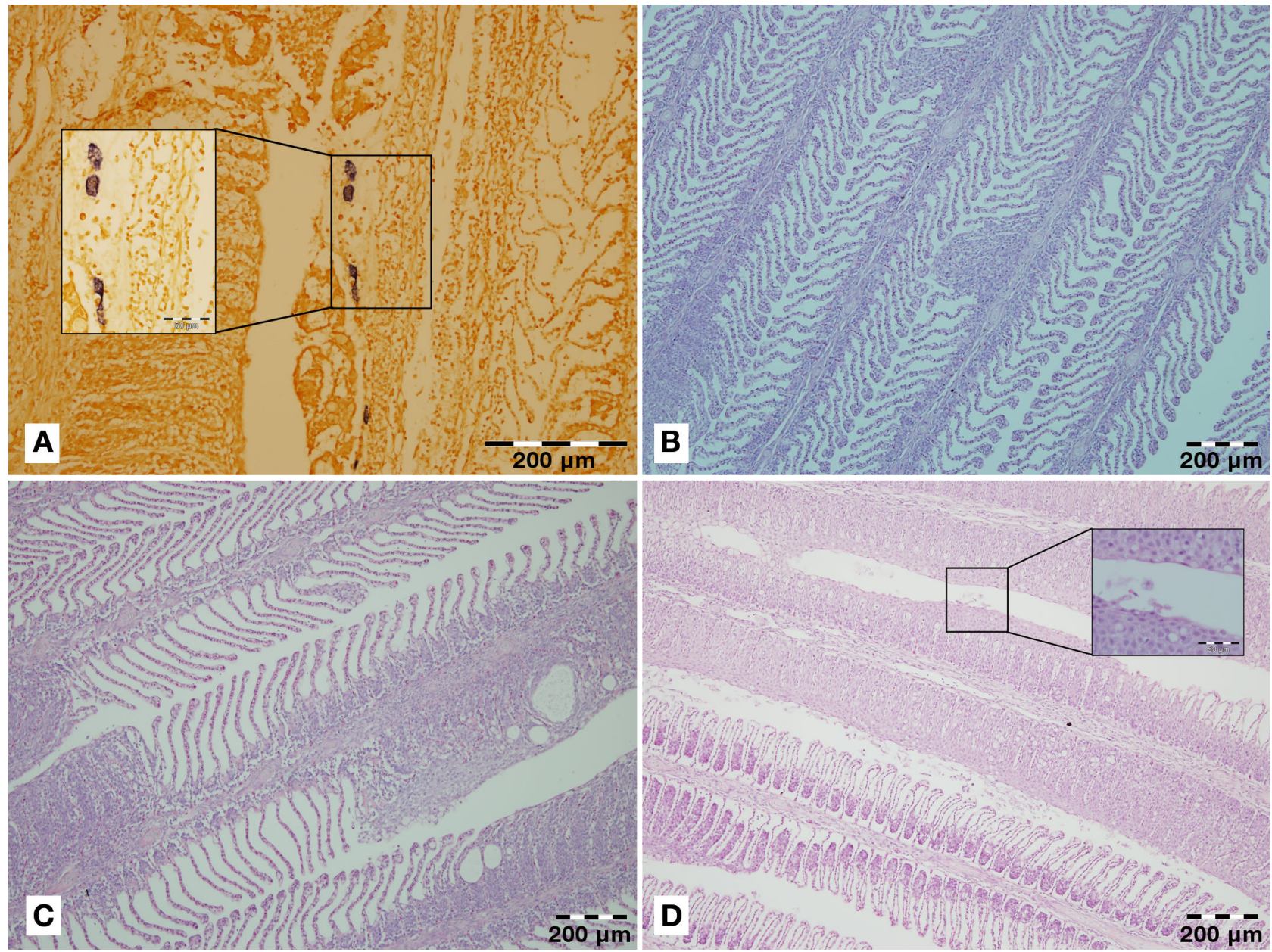

Fig. 5. (A) In situ hybridisation using species-specific oligonucleotide probes on Atlantic salmon gill sections examined from the study site. (Inset) Reactive dark cells indicate the presence of $N$. perurans. (B-D) Examples of the different levels of pathology observed in the gills of Atlantic salmon during this study: (B) a score of ' 1 ' was assigned to a section where $<10 \%$ pathology was observed; $(C)$ a histological score of ' 2 ' where there is between 10 and $50 \%$ pathology observed; (D) gills with $>50 \%$ pathology showing complete loss of structure due to hyperplasia and fusion and (inset) amoeba present (histological score of '3')

tive such as Davidson's may have resulted in higher retention of amoebae on the gills sampled (Cadoret et al. 2013); however, it was more practical to use buffered formalin which is also routinely used in fish histopathology. The sensitivity of the real-time assay was demonstrated by the fact that positive fish were already detected by Week $12(10 \%$ of fish tested were positive), and by Week 16, all fish tested were positive for $N$. perurans.

Following the increase in mortality and diagnosis of AGD, the site undertook a freshwater treatment of every cage in Week 18 to treat for the disease. Samples collected 4 d post-treatment, during Week 19, showed a reduction in the percentage of PCR-positive fish $(10 \%)$, which is in line with previous findings where a reduction in the number of amoebae was observed following freshwater bathing (Clark et al. 2003). Both the average gill and histological scores were reduced by Week 21, as it can take up to $4 \mathrm{wk}$ post-treatment for gills to fully recover (Findlay et al. 2000). However, both gross and histological gill scoring can be misleading due to the presence of scarring from the previous infection, requiring adjustment in their interpretation. Due to some amoebae remaining and all cages not receiving treatments simultaneously, re-infection can occur as early as 1 wk posttreatment and can increase in severity over the following weeks (Clark et al. 2003, Adams \& Nowak 2004). This study confirmed a similar re-infection profile where an increase in the number of PCR-pos- 
itive fish by Week 21, only 3 wk following the first freshwater bath, was observed. Interestingly, it was $6 \mathrm{wk}$ post-treatment when an increase in the average gill score and histology score was observed, and a second full site treatment was required in Week 24. In total, there were 6 recorded freshwater bath treatment events over the course of the study, the first 2 involving treatment of each cage on site while the 4 subsequent treatments were administered to a subset of specifically selected cages.

The PCR assay developed in this study was shown to have a beneficial role in monitoring the progress of the disease, in particular with detection of the amoeba 3 wk prior to detection via gross pathology. The ability of this assay to detect amoebae a number of weeks prior to traditional diagnostics can potentially provide farm managers with valuable information to effectively plan treatments. Such information is important where infrastructure (wellboats) and the resources required (access to freshwater) for treatment are limited (Nowak 2012). As traditional detection methods require advanced stages of the disease in a greater proportion of the population, use of molecular-based diagnostic tools could allow for earlier intervention strategies. Although the traditional screening methods (gill scores, wet-preparations and histology) are important tools for on-site monitoring of AGD, significant experience is required as amoebae can be difficult to differentiate from gill epithelial cells and observation of amoebae cells is not always possible, particularly when infection levels are low (Munday et al. 2001).

Interestingly, the levels of weekly mortalities recorded during the outbreaks of AGD on the surveillance site were slightly lower than that observed in outbreaks of AGD in Tasmania where levels of 2 to $4 \%$ per week were recorded in fish weighing 1 to $2 \mathrm{~kg}$ (Munday et al. 2001). In this study, the weekly mortality peaked at just over $2 \%$ in the first year of production when fish weighed $<1 \mathrm{~kg}$. Following a reduction in temperature in January and February 2014 and fish weights increasing $>1 \mathrm{~kg}$, the percentage mortality returned to background levels for the remainder of the study.

This is the first study of AGD conducted under field conditions over a full marine production cycle on a farm in Ireland. During this study, there were 3 separate outbreaks of AGD on this site. Each outbreak was preceded by a rise in the number of fish testing positive by PCR and subsequently by increased gill and histology scores. The development of an early detection method that is economical, sensitive and specific to diagnose AGD in the early stages of infection is an extremely valuable tool. As with other diagnostic methods, further considerations are required, and all on-site factors and observations must be taken into account when preparing a diagnosis (Munday et al. 2001). This was evidenced in the second year of production when PCR-positive fish, gill scores and histology scores indicative of infection with $N$. perurans were recorded, although mortality levels remained low. While the immune response of Atlantic salmon to $N$. perurans is still poorly understood, there is some evidence to suggest that the fish that have survived an initial challenge of AGD develop some resistance or tolerance to the parasite (Vincent et al. 2006, Taylor et al. 2009, ValdenegroVega et al. 2015). This may also be influenced by differing genetic traits for the mechanisms involved in the resistance to the first and subsequent infections (Kube et al. 2012).

In conclusion, the assay developed in this study demonstrated potential as a tool to complement existing techniques for monitoring AGD. Future studies, utilising non-lethal gill swabs, will further enhance monitoring capabilities for AGD by the aquaculture industry.

Acknowledgements. This project is funded under the Marine Institute Research Fellowship Programme (project MEFSS/PhD/2013) in conjunction with the Galway-Mayo Institute of Technology. The authors acknowledge Vet Aqua International, Marine Harvest Ireland and Cathy Hickey (Marine Institute) for their assistance throughout the study.

\section{LITERATURE CITED}

Adams MB, Nowak BF (2001) Distribution and structure of lesions in the gills of Atlantic salmon, Salmo salar L., affected with amoebic gill disease. J Fish Dis 24:535-542

Adams MB, Nowak BF (2004) Sequential pathology after initial freshwater bath treatment for amoebic gill disease in cultured Atlantic salmon, Salmo salar L. J Fish Dis 27: 163-173

Adams MB, Ellard K, Nowak BF (2004) Gross pathology and its relationship with histopathology of amoebic gill disease (AGD) in farmed Atlantic salmon, Salmo salar L. J Fish Dis 27:151-161

Adams MB, Crosbie PBB, Nowak BF (2012) Preliminary success using hydrogen peroxide to treat Atlantic salmon, Salmo salar L., affected with experimentally induced amoebic gill disease (AGD). J Fish Dis 35:839-848

Barta JR, Martin DS, Liberator PA, Dashkevicz M and others (1997) Using complete small subunit ribosomal DNA sequences relationships among eight Eimeria species infecting fowl inferred domestic using complete subunit ribosomal DNA sequences. J Parasitol 83:262-271

Baxter EJ, Rodger HD, McAllen R, Doyle TK (2011) Gill disorders in marine-farmed salmon: investigating the role of hydrozoan jellyfish. Aquacult Environ Interact 1:245-257 Bermingham ML, Mulcahy MF (2007) Neoparamoeba sp. 
and other protozoans on the gills of Atlantic salmon Salmo salar smolts in seawater. Dis Aquat Org 76:231-240

Bridle AR, Crosbie PBB, Cadoret K, Nowak BF (2010) Rapid detection and quantification of Neoparamoeba perurans in the marine environment. Aquaculture 309:56-61

Bruno D, Collet B, Turnbull A, Kilburn R and others (2007) Evaluation and development of diagnostic methods for Renibacterium salmoninarum causing bacterial kidney disease (BKD) in the UK. Aquaculture 269:114-122

Bustin SA, Benes V, Garson JA, Hellemans J and others (2009) The MIQE guidelines: minimum information for publication of quantitative real-time PCR experiments. Clin Chem 55:611-622

Bustos PA, Young ND, Rozas MA, Bohle HM, Ildefonso RS, Morrison RN, Nowak BF (2011) Amoebic gill disease (AGD) in Atlantic salmon (Salmo salar) farmed in Chile. Aquaculture 310:281-288

> Cadoret K, Bridle AR, Leef MJ, Nowak BF (2013) Evaluation of fixation methods for demonstration of Neoparamoeba perurans infection in Atlantic salmon, Salmo salar L., gills. J Fish Dis 36:831-839

> Clark A, Nowak BF (1999) Field investigations of amoebic gill disease in Atlantic salmon, Salmo salar L., in Tasmania. J Fish Dis 22:433-443

> Clark G, Powell M, Nowak B (2003) Effects of commercial freshwater bathing on reinfection of Atlantic salmon, Salmo salar, with amoebic gill disease. Aquaculture 219: 135-142

Crosbie PBB, Bridle AR, Cadoret K, Nowak BF (2012) In vitro cultured Neoparamoeba perurans causes amoebic gill disease in Atlantic salmon and fulfils Koch's postulates. Int J Parasitol 42:511-515

> Doyle TK, De Haas H, Cotton D, Dorschel B and others (2008) Widespread occurrence of the jellyfish Pelagia noctiluca in Irish coastal and shelf waters. J Plankton Res 30:963-968

> Dyková I, Figueras A, Novoa B, Casal JF (1998) Paramoeba sp., an agent of amoebic gill disease of turbot Scophthalmus maximus. Dis Aquat Org 33:137-141

> Dyková I, Figueras A, Peric Z (2000) Neoparamoeba Page, 1987: light and electron microscopic observations on six strains of different origin. Dis Aquat Org 43:217-223

> Findlay VL, Zilberg D, Munday BL (2000) Evaluation of levamisole as a treatment for amoebic gill disease of Atlantic salmon, Salmo salar L. J Fish Dis 23:193-198

> Fringuelli E, Gordon AW, Rodger H, Welsh MD, Graham DA (2012) Detection of Neoparamoeba perurans by duplex quantitative Taqman real-time PCR in formalin-fixed, paraffin-embedded Atlantic salmonid gill tissues. J Fish Dis 35:711-724

> Graham DA, Fringuelli E, Wilson C, Rowley HM and others (2010) Prospective longitudinal studies of salmonid alphavirus infections on two Atlantic salmon farms in Ireland; evidence for viral persistence. J Fish Dis 33:123-135

> Gunson RN, Collins TC, Carman WF (2006) Practical experience of high throughput real time PCR in the routine diagnostic virology setting. J Clin Virol 35:355-367

Karlsbakk E, Olsen AB, Einen ACB, Mo TA and others (2013) Amoebic gill disease due to Paramoeba perurans in ballan wrasse (Labrus bergylta). Aquaculture 412-413: 41-44

Kent ML, Sawyer TK, Hedrick RP (1988) Paramoeba pemaquidensis (Sarcomastigophora: Paramoebidae) infestation of the gills of coho salmon Oncorhynchus kisutch reared in sea water. Dis Aquat Org 5:163-169
Kongtorp RT, Halse M, Taksdal T, Falk K (2006) Longitudinal study of a natural outbreak of heart and skeletal muscle inflammation in Atlantic salmon, Salmo salar L. J Fish Dis 29:233-244

- Kube PD, Taylor RS, Elliott NG (2012) Genetic variation in parasite resistance of Atlantic salmon to amoebic gill disease over multiple infections. Aquaculture 364-365: $165-172$

> Marcos-López M, Mitchell SO, Rodger HD (2014) Pathology and mortality associated with the mauve stinger jellyfish Pelagia noctiluca in farmed Atlantic salmon Salmo salar L. J Fish Dis (in press) doi:10.1111/jfd.12267

> Martenot C, Oden E, Travaillé E, Malas JP, Houssin M (2010) Comparison of two real-time PCR methods for detection of ostreid herpesvirus 1 in the Pacific oyster Crassostrea gigas. J Virol Methods 170:86-89

Mitchell S, Rodger H (2007) Pathology of wild and cultured fish affected by a Karenia mikimotoi bloom in Ireland, 2005. Bull Eur Assoc Fish Pathol 27:39-42

> Mitchell SO, Baxter EJ, Holland C, Rodger HD (2012) Development of a novel histopathological gill scoring protocol for assessment of gill health during a longitudinal study in marine-farmed Atlantic salmon (Salmo salar). Aquacult Int 20:813-825

Monis PT, Giglio S (2006) Nucleic acid amplification-based techniques for pathogen detection and identification. Infect Genet Evol 6:2-12

> Morrison RN, Crosbie PBB, Nowak BF (2004) The induction of laboratory-based amoebic gill disease revisited. J Fish Dis 27:445-449

> Mouton A, Crosbie P, Cadoret K, Nowak B (2014) First record of amoebic gill disease caused by Neoparamoeba perurans in South Africa. J Fish Dis 37:407-409

Munday BL, Zilberg D, Findlay V (2001) Gill disease of marine fish caused by infection with Neoparamoeba pemaquidensis. J Fish Dis 24:497-507

Nowak BF (2012) Neoparamoeba perurans. In: Woo PTK, Buchmann K (eds) Fish parasites: pathobiology and protection, 1st edn. CAB International, Oxfordshire, p 1-18

Nowak B, Carson J, Powell M, Dykova I (2002) Amoebic gill disease in the marine environment. Bull Eur Assoc Fish Pathol 22:144-147

> Nowak B, Valdenegro-Vega V, Crosbie P, Bridle A (2014) Immunity to amoeba. Dev Comp Immunol 43:257-267

Palmer R, Carson J, Ruttledge M, Drinan E, Wagner T (1997) Gill disease associated with Paramoeba, in sea reared Atlantic salmon in Ireland. Bull Eur Assoc Fish Pathol 17: 112-114

Parsons H, Nowak B, Fisk D, Powell M (2001) Effectiveness of commercial freshwater bathing as a treatment against amoebic gill disease in Atlantic salmon. Aquaculture 195:205-210

> Purcell MK, Getchell RG, McClure CA, Garver KA (2011) Quantitative polymerase chain reaction (PCR) for detection of aquatic animal pathogens in a diagnostic laboratory setting. J Aquat Anim Health 23:148-161

Rodger HD (2014) Amoebic gill disease (AGD) in farmed salmon (Salmo salar) in Europe. Fish Vet J 14:16-26

Rodger HD, McArdle JF (1996) An outbreak of amoebic gill disease in Ireland. Vet Rec 139:348-349

> Rodger HD, Murphy K, Mitchell SO, Henry L (2011) Gill disease in marine farmed Atlantic salmon at four farms in Ireland. Vet Rec 168:668

Steinum T, Kvellestad A, Rønneberg LB, Nilsen $\mathrm{H}$ and others (2008) First cases of amoebic gill disease (AGD) 
in Norwegian seawater farmed Atlantic salmon, Salmo salar L., and phylogeny of the causative amoeba using 18S cDNA sequences. J Fish Dis 31:205-214

Taylor RS, Muller WJ, Cook MT, Kube PD, Elliott NG (2009) Gill observations in Atlantic salmon (Salmo salar, L.) during repeated amoebic gill disease (AGD) field exposure and survival challenge. Aquaculture 290:1-8

Valdenegro-Vega VA, Polinski M, Bridle A, Crosbie P, Leef M, Nowak BF (2015) Effects of single and repeated infections with Neoparamoeba perurans on antibody levels and immune gene expression in Atlantic salmon (Salmo salar). Fish Shellfish Immunol 42:522-529

Editorial responsibility: Marianne Holmer, Odense, Denmark
Vincent BN, Morrison RN, Nowak BF (2006) Amoebic gill disease (AGD)-affected Atlantic salmon, Salmo salar L., are resistant to subsequent AGD challenge. J Fish Dis 29: 549-559

Young ND, Crosbie PBB, Adams MB, Nowak BF, Morrison RN (2007) Neoparamoeba perurans n. sp., an agent of amoebic gill disease of Atlantic salmon (Salmo salar). Int J Parasitol 37:1469-1481

Young ND, Dyková I, Nowak BF, Morrison RN (2008) Development of a diagnostic PCR to detect Neoparamoeba perurans, agent of amoebic gill disease. J Fish Dis 31: 285-295

Submitted: February 5, 2015; Accepted: August 22, 2015 Proofs received from author(s): November 3, 2015 